\title{
Film Music in Czech Music Periodicals in the 1960s
}

\author{
Věra Šímová
}

Czech film underwent a great development in the 1960s. This decade is often even called "the golden era of the Czech film". Due to the political and social thaw in Czechoslovakia, its film production, after years of isolation, gradually could again be confronted with world cinematography. Many more foreign films came to be imported than in the previous or the subsequent decades and their selection was more liberal. Beside the domestic filmmakers of the older and middle generations, the fresh graduates of Filmová a televizní fakulta Akademie múzických umění v Praze (FAMU) [Film and TV School of Academy of Performing Arts in Prague] asserted themselves (Miloš Forman, Jaromil Jireš, Jan Schmidt, Jiří Menzel, Věra Chytilová, Pavel Juráček, Ivan Passer, Jaroslav Papoušek, Antonín Máša, Evald Schorm, Jan Němec, Juraj Herz, Hynek Bočan, etc.), ${ }^{1}$ the so-called "second generation of FAMU". From their ranks, the most progressive stream of Czech cinematography of the 1960s was formed, the Česká nová vlna [Czech New Wave]. Films by these directors are among the most precious fruit of the Czechoslovak film production in that decade.

In film music the situation was similar. Music began to change on the basis of purely artistic factors. Contacts with music of Western Europe music were re-established, new techniques of composition made themselves felt even in film music. Aleatorics and timbre music, together with the development of recording and reproducing techniques, radically affected the conception of sound both in concert music and in film music. The influence of socialist realism receded. The young directors who in their films often treated contemporary themes, understandably invited for cooperation contemporary musicians. Thus the New Music composers began to collaborate with the film - Jan Klusák, Luboš Fišer, Jan Novák, and so did composers of jazz music, such as Karel Velebný and Luděk Hulan. Due to the great popularity of pop music influenced by rock, its authors found opportunities for treating contemporary themes in films (Jiří Šlitr, Jiří Malásek, Petr Hapka, Karel

\footnotetext{
$1 \quad$ See Ludvík Havel, Český film 1945-1998 [Czech Film 1945-1998] (Brno, 1998), p. 9.
} 
Svoboda, Ladislav Štaidl). ${ }^{2}$ This and the way this development in film music was perceived by Czech music specialists in professional journals, is the subject of the following paper.

The field thus defined is comprised in particular of three periodicals: Hudební věda [Musicology], Opus musicum and Hudební rozhledy [Music Review]. Hudební véda (regularly issued since 1964) did not pay any attention to film music in that period. The same holds for the first two volumes of Opus musicum, from 1969 and 1970. Thus in the 1960s the only music journal Hudebni rozhledy (issued since 1948) informed in greater detail about the music in Czech, Slovak, and eventually in imported foreign films. ${ }^{3}$ The authors of the majority of these articles are two Czech musicologists and journalists - Milan Kuna, who in the 1960s published two books on film music (Hudba v krátkém filmu [Music in Short Film], Prague, 1960 and Zvuk a hudba ve filmu: Kanalýze zvukové dramaturgie filmu [Sound and Music in Film: Analysis of Sound Dramaturgy of Film], Prague, 1969), and Jiří Pilka. The latter began to deal with film music while he was still a student at the Philosophical Faculty, Charles University in Prague, from which he graduated with the M.A. thesis Otázky filmové hudby: Filmová hudba Jiřiho Srnky [Issues of Film Music: Film Music of Jiři Srnka]. ${ }^{4}$ At the beginning of the sixties he published the popularizing book Tajemství filmové hudby [Secrets of Film Music] (Prague, 1960). Pilka was also a member of the Filmový a televizní svaz (FITES) [Film and Television Union] and in 1966-1970 was active in its presidium. Occasional writers on film music in Hudebni rozhledy in the 1960s were Jan F. Fischer, Vladimír Bor, Lubomír Dorůžka, Pavel Skála, Vratislav Dejmek, Vladimír Šefl, and a few more.

Texts on music published in Hudebni rozhledy can be classified in three groups. The most frequent were short reviews or brief analyses of music in one or several films, to the extent of c. 2,500 to 4,500 keystrokes, centralized in the column Film. The second group is comprised of longer studies and papers dealing mainly in a general way with the issues of film music. The third category contains the rest of the articles and the reports, with no uniform theme or form. They mainly refer to various competitions in film music, reports on film festivals, and reviews on books on the theme of film music. We are going to deal with each of the three groups.

I.

In 1960 a new column was opened in Hudební rozhledy, entitled Film and devoted to film music. Articles on music for films were published already in the previous years but rather occasionally, with no unity in form or content. They were mainly informative, often not focused on the music but on the film as a whole. In 1960-1964, when the column Film appeared, a total of 39 articles were published, dealing with music of 52 films. Of these, 47 were Czech, 4 Slovak and 2 Soviet Russian. Jiři Pilka, the author of the 7 articles

\footnotetext{
2 Antonín Matzner and Jiři Pilka, Česká filmová hudba [Czech Film Music] (Prague, 2002), p. 266.

3 A sort of reflection of film music was also provided by non-musical periodicals, especially the specialized film journal Film a doba [Film and Times].

4 Published as Filmová hudba Jiř́ho Srnky [Film Music of Jiří Srnka] (Prague, 1957).
} 
in 1960, discussed, rather briefly, several films in each article. The 32 reviews by Milan Kuna, the only contributor to the column Film in 1961-1964 (except for one article by Vladimír Bor), are more detailed and focus on music in a single film. From the texts it is not apparent in what way the films were chosen for analysis, whether the writers approached the films systematically or just responded to those they had seen (more or less accidentally) in cinemas. Their selection, however, is, with some exceptions, a fairly representative sample of music in film production of the years 1960-1964, when music to films made in those years, and the names of the composers are taken into account. From the list of the composers of film music found in the book Čskoslovenské filmy 1960-1965 [Czechoslovak Films 1960-1965] ${ }^{5}$ it is clear that music for most films of 1960-1964 was composed by Zdeněk Liška: there were thirty of them. His music is also appropriately discussed in the column Film (in eight analyses). Music for more than ten films was composed by the following composers (in brackets is first given the number of the films for which they composed music in this five-year-long period and after the line of fraction follows the number of films, assessed by Pilka and Kuna): Svatopluk Havelka (16/3), Jiří Srnka (15/4), Evžen Illín (15/3), Štěpán Lucký (14/2), Miloš Vacek (12/4) and William Bukový (12/3). In the majority of these composers thus Hudební rozhledy discussed c. $20-30 \%$ of their work for the film. A few more composers, who in this period worked on fewer than ten films, are dealt with in the column Film once or twice only. This group includes e.g. composers from the sphere of New Music, who in the early 1960s began to co-operate with film - Jan Novák, Jan Klusák, and Luboš Fišer.

We are told, however, relatively little about music for films of the progressive Česká nová vlna. Kuna commented the films of these directors only twice, each time with a different evaluation. They are the film by Věra Chytilová $O$ něčem jiném [On Something Else] (music by Jiř́ Šlitr) and Křik [Cry] by Jaromil Jireš (music by Jan Klusák), both from 1963. The reviewer believes that the sound dramaturgy of the former film and Slitr's film music is not "an equal partner in expression to the visual component" and often remains a mere sound backdrop. ${ }^{6}$ A quite different impression arises from Klusák's sound dramaturgy in the film Krik. There he found interesting interlinking of music, dialogue and picture, when each of the components has a specific communication for the spectator. Kuna speaks of "rare relative independence of music in the film" in that period. ${ }^{7}$ The principal reason why Kuna did not analyze more films of the Česká nová vlna is that their overwhelming majority were made after the column Film in Hudební rozhledy was discontinued (that is after 1964).

The articles, after a sort of "settling" during the year 1960, when the column Film was established, was preserved during its whole duration. It is a column on the outer margin of the page (or two pages) of Hudebni rozhledy, which takes up one third of it

\footnotetext{
Šárka Bartošková, Československé filmy 1960-1965 [Czechoslovak Films 1960-1965], vol. 2, Filmografie tviorčich pracovníků [Filmography of Creative Artists] (Prague, 1966), p. 320-331.

6 Milan Kuna, "Film”, Hudebni rozhledy, 17 (1964), p. 106.

7 Milan Kuna, "Film”, Hudební rozhledy, 17 (1964), p. 422.
} 
and is designated by its own logo. The content depends on the character of the film and in particular on the film music. The narrative of the film is or is not told briefly and the same holds for various intentions and the name of the film director. The work and names of other associates, such as the script writer, cameraman, etc. are mentioned only if they are in some way connected with the music. Naturally the greatest attention is paid to the film music - and this is done from various aspects. It is specified what role the music fills in the film, whether it is merely a backdrop or whether it is an independent component which brings its own message to the audio-viewer of the film, whether it describes the character of the protagonists and of the milieu and period in which the story of the film is set, etc. The reviewer also watches what kind of instruments were used by the composer, what genre he chose, what use he made of silence and various sounds, whether he only used his own music or resorted to pre-composed music. ${ }^{8}$ There are many varieties of assessment of film music and many points of view. A particular analysis sometimes brings the authors to more general thoughts on the quality of Czech film music, the course of the cooperation of film directors and composers. Often they regret the one-sided choice of composers or the very short time available for composing the music. From the ratio of positive and negative assessments of films one can deduce a great objectivity of the reviewers. Although positive assessment prevails, not infrequently they raise objections of various kinds to the film music. We do not find here a "blind" popularity of a particular composer - in most reviews we find a wide spectrum of opinions and criteria.

A similar character and extent as in the column Film is found in some articles printed outside this column. They are texts concentrating in a more general way on a particular issue of film music, but with numerous examples from particular films ${ }^{9}$ or they were written by other authors (Antonín Matzner, Pavel Skála and a few more). They may be a translation of a foreign review of a foreign film or they were published when the column Film was no longer in existence.

II.

The second group of texts on music is comprised of larger studies and articles. More than half of them deal in a rather general way with the aesthetic-theoretical, technical and administrative issues of Czech film music. Among the most frequent issues are the tendency of development in film music (departure from symphonism, a more frequent use of chamber ensembles, the entry of jazz and popular music in films, the use of sound effects - noises, etc.). A separate study by Milan Kuna deals with the use of pre-composed

8 The use of pre-composed music in films in the world became fairly frequent and is found in Czech films as well. In Hudebni rozhledy in the column Film was very positively received the work with pre-composed music in the films Noční host [Night Guest] of the director Otakar Vávra (music by Jiři Srnka) and Až prijide kocour [When the Cat Comes] by Vojtěch Jasný (music by Svatopluk Havelka). See Milan Kuna, "Film", Hudební rozhledy, 14 (1961), p. 877 and Milan Kuna, "Film", Hudební rozhledy, 16 (1963), p. 862-863.

9 E.g. Milan Kuna, "Otázky formy ve filmové hudbě” [Issues of Form in Film Music], Hudební rozhledy, 15 (1962), p. 778. 
music in films and with the typology of film music from the aspect of its cooperation with the image. ${ }^{10}$ New technical devices for screening a sound film (stereophonic cinema, polyécran, Circorama and laterna magica) are presented in an article by Jiří Pilka, Hudba $v$ náruči techniky [Music Embraced by Technology] of 1960, in which the author determines the specificity of each variant and deduces the contributions for the musical dramaturgy of the film. ${ }^{11}$ Next the influence of foreign cinematography on the work with music and sound (mainly the effect of Italian Neo-realism on the decreasing share of music in films), the new contemporary themes in films and their setting to music are discussed in Hudební rozhledy. It is pointed out that conditions for composers of film music are rather poor (mainly because of the short time available for composing), there is insufficient cooperation between the film director and the composer in the conception of the sound component of the film from the very beginning, ${ }^{12}$ the training of film directors is unsatisfactory, and there is a lack of dramatic feeling in (some) composers. The lack of interest on Czech reviewers and musicologists in film music and the need of aesthetical and theoretical studies in this field are also emphasized. Similar topics were mentioned and analyzed from various aspects in a wide discussion on film music, held by Hudební rozhledy and the film section of the Svaz československých divadelních a filmových umělců [Union of Czechoslovak Theatre and Film Artists] held in 1962 in the Film Club in Prague. The discussion was attended by film directors, dramaturgists, heads of film groups, composers and critics. The recording of the discussion was reprinted in Hudebni rozhledy. ${ }^{13}$

Among longer studies are those dealing with the issue of operas made into films, the film musical, film musical revue and music film in television. ${ }^{14}$ A unique contribution is the detailed analysis of musical dramaturgy in the film Accattone (1961) by the Italian director Pier Paolo Pasolini, in 1970 written by Vratislav Dejmek - there was no other study to such extent dealing with music of a foreign, non-Soviet film. ${ }^{15}$

10 Milan Kuna, "K problémům estetiky filmové hudby" [On the Problems of Aesthetics of Film Music], Hudebni rozhledy, 14 (1961), p. 946-948.

11 Jiři Pilka, "Hudba v náručí techniky" [Music Embraced by Technology], Hudební rozhledy, 13 (1960), p. $820-821$.

12 The composer generally received a cut film and so could not plan the sound dramaturgy while the film was being shot. As an ideal example of cooperation of the director and the composer, the pair Sergei Eisenstein - Sergei Prokofiev and in this country Jiří Trnka - Jan Trojan are often quoted.

13 "Spolutvůrce filmu" [Co-author of the Film], Hudební rozhledy, 15 (1962), p. 280-284.

14 E.g. I. Ryžkin, “Opera a film” [Opera and Film], Hudební rozhledy, 14 (1961), p. 195-196. Milan Kuna, "Dramaturgie filmové Rusalky" [Dramaturgy of the Film Version of Rusalka], Hudební rozhledy, 16 (1963), p. 447-448. Ivan Poledňák, "Starci na chmelu - filmový musical" [Starci na chmelu (Hop-picking Old Men) - A Film Musical], Hudební rozhledy, 17 (1964), p. 892. Lubomír Dorůžka, "Kdyby tisíc klarinetů" [If One Thousand Clarinets - title of Czech film musical], Hudební rozhledy, 18 (1965), p. 252-253. Jiři Pilka, "Hudební filmy naší televize" [Music Films of the Czech Television], Hudební rozhledy, 20 (1967), p. 558-561.

15 Vratislav Dejmek, "Poznámky k hudební dramaturgii filmového debutu P. P. Pasoliniho" [Notes on the Music Dramaturgy of the Film Debut of P. P. Pasolini], Hudební rozhledy, 23 (1970), p. 84-86. 
III.

The third, less compact group is comprised of the rest of shorter articles and news items dealing with film music, with various form and content. They mainly inform the readers of various film competitions, film festivals, and book reviews.

A separate section is formed of texts on competitions in film music. In 1963, on the initiative of the Filmový symfonický orchestr [Film Symphonic Orchestra], the Československý film [Czechoslovak Film], in cooperation with the Svaz československých skladatelů [Union of Czechoslovak Composers], the Český hudební fond [Czech Music Foundation], and the Slovenský hudební fond [Slovak Music Foundation], announced a competition for the best work of music made for the Czechoslovak film in $1963 .{ }^{16}$ This competition took place every year until 1967, with the aim of a systematic survey of the Czech film music. The competing went on in three to six categories, according to the type of the film. ${ }^{17}$ The principal criteria were: how music with the artistic level increases the value of the film as a monolithic work, how it meets its dramatic function, how to it captures the character and genre of the film and what is the professional level of the music from the aspect of composition techniques. The competition was proclaimed in Hudební rozhledy, and this journal also brought the results and occasionally more detailed information in the form of articles with a short analysis of the music of the awarded films and the reasons of their success, or they had the form of a recording of the discussion of the members of the jury. ${ }^{18}$

Among the reviews of literature of music in Hudebni rozhledy there was, in the 1960s, an assessment of two works discussing film music. In 1960 it was Jan F. Fischer's review of the book by Vladimír Bor and Štěpán Lucký, Trojan - filmová hudba [Trojan - Film Music] (Prague, 1958), in which the author regards positively the contribution of a short but readable book on a theme often neglected in this country - the film music. ${ }^{19}$ The book by Zofia Lissa, Estetyka muzyki filmowej [Aesthetics of Film Music] (Cracow, 1964) was presented in Hudebni rozhledy in the very year of its publication. ${ }^{20}$

After introducing the various types of texts on film music, as they were published in Hudebni rozhledy in the 1960s, let us turn to the conclusion and say through what sort of development within this decade they passed and compare the situation to several

16 For greater details see Vladimír Šefl, "Film potřebuje hudbu" [The Film Needs Music], Hudební rozhledy, 17 (1964), p. 355-358.

17 During the competitions the categories changed and split but they always covered mainly: feature films, puppet films, animated cartoons, popular scientific, documentary and musical films as well as original television inscenation.

18 Vladimír Šefl, "Film potřebuje hudbu", Hudební rozhledy, 17 (1964), p. 355-358. "Hudba a film" [Music and Film] (recording of a discussion), Hudební rozhledy, 19 (1966), p. 355-358.

19 Jan F. Fischer, "Vladimír Bor - Štěpán Lucký, Trojan - filmová hudba (Prague, 1958)" (review) Hudební rozhledy, 13 (1960), p. 172.

20 Anonymous, “O filmové hudbě” [On Film Music], Hudební rozhledy, 17 (1964), p. 723. 
preceding and subsequent years. We shall also confront this state with the development of Czech film music and try to find any correspondence between the two, and establish whether Hudební rozhledy reflected the development of Czech film music in that decade in a proper way.

As it was said above, the column Film with analyses of (mainly Czech) films and its music was in existence in 1960-1964. Articles of a similar kind as in the column but of different form were published irregularly during the whole decade. The majority of longer studies are found in Hudebni rozhledy in the first half of the 1960s, reports on competitions in the years of its existence, that is in 1963-1968 and, the two reviews of books on music, referred to above, appeared in 1960 and 1964. When the more substantial texts (column Film, studies and reviews) are considered, it must be said that the first half of the sixties produced six times as many articles on music as the second half. This is on average eleven texts per year in the first half and fewer than two articles per year in the second half of the decade. A comparison of the quantity of articles in several preceding and following years reveals that in 1957-1959 and 1971-1973 the situation is very similar to that in the second half of the decade under study. What conclusions may be drawn from this on the development of Czech film music? A great increase in studies and reviews of Czech film music in the first half of the sixties corresponds to its intensive development and shows the transformation the film went through. The suppression of this trend already at the beginning of the second half is in no correspondence with the situation in film music. This music continued to develop fairly freely until the end of the decade and the middle of the sixties was no major milestone. The suppression of the articles on film music is rather a reflection of the editorial situation in Hudebni rozhledy or of the lack of interest in theoretical and analytical texts and information on film music, regardless of its continuing development.

Translated by Jaroslav Peprník

\section{Die Filmmusik in den tschechischen Musikperiodika in den 60er Jahren des 20. Jahrhunderts}

\section{Zusammenfassung}

In den sechziger Jahren des 20. Jahrhunderts setzte dank einer politisch-gesellschaftlichen Liberalisierung in der damaligen Tschechoslowakei eine bedeutsame kreative Entwicklung im Film und in der Filmmusik ein. Aufgrund der Wiederherstellung von Kontakten mit der westeuropäischen Musik begann man neben anderem neue Kompositionstechniken zu verwenden; es kam zu Veränderungen innerhalb der Filmmusik als solcher und zu einer funktionell besser entwickelten Verwendung von realistischen Tönen und der Stille; darüber hinaus fanden Jazz- und Popmusik Eingang in den Film. 
Der Beitrag beschäftigt sich mit der Reflexion dieser Entwicklung in den tschechischen Musikperiodika, vor allem in Hudební rozhledy [Musikrundschau]. Die Texte über die Filmmusik sind nach ihrem Umfang, nach ihrem Inhalt und ihrer Form in drei Gruppen eingeteilt. Im Rahmen dieser Einteilung wurden dann deren Entwicklungen verfolgt, wobei diese ausführlicher vorgestellt und aus verschiedenen Blickwinkeln behandelt wurden. Zum Schluss des Beitrags vergleicht die Autorin den Zustand der Musik-Filmkritik mit der Situation in der Filmmusik in einer festgelegten Dekade und in mehreren vorhergehenden und nachfolgenden Jahren.

\section{Filmová hudba v českých hudebních periodikách v 60. letech 20. století}

\section{Shrnutí}

V 60. letech 20. století došlo díky politicko-společenskému uvolnění v tehdejším Československu k výraznému tvůrčímu rozvoji filmu a filmové hudby. Díky znovuobnovení kontaktů se západoevropskou hudbou se začali mimo jiné uplatňovat nové kompoziční techniky, docházelo k proměnám vlastní filmové hudby, $\mathrm{k}$ funkčnějšímu využití reálných zvuků a ticha, průniku jazzové a populární hudby do filmu. Př́spěvek se zabývá tím, jak tento vývoj reflektovala česká hudební periodika, především Hudební rozhledy. Texty o filmové hudbě jsou podle rozsahu, obsahu a formy rozčleněny do tří skupin. Poté je v rámci tohoto dělení sledován jejich vývoj, jsou podrobněji představeny a nazírány z různých hledisek. V závěru příspěvku autorka porovnává stav hudebně filmové kritiky se situací v české filmové hudbě ve vymezené dekádě a několika předchozích a následujících letech.

\section{Keywords}

Film music; Czech film music; Czech music periodicals; 1960s; Hudební rozhledy. 